\title{
UVODNIK
}

\section{RAZVOJ OBRAMBNEGA SISTEMA}

V začetku leta, ko smo k pisanju člankov vabili avtorje, smo vedeli, da se na področju varnosti obetajo novosti, sijih pa nismo prav konkretno predstavljali. Vedno ko govorimo o varnosti, obrambi in vojski, radi omenimo globalni svet in nenehne spremembe ter tako že skoraj logično uporabimo izraz transformacija. Ta naj bi na kratko pojasnila vso zapletenost sodobnega sveta na tem področju, pa to le ni tako. Zavezništvo ima v Norfolku v ZDA poveljstvo za transformacijo, katerega poslanstvo so izobraževanje, usposabljanje in vaje, razvoj novih konceptov ter promocija interoperabilnosti med državami članicami. V državah članicah so Natovi centri odličnosti za različna področja, vsaka članica ima svoje vojaškoizobraževalne institucije in fakultete, ki so namenjene razvoju varnostnih vsebin, in različne institucije »think tank«.

Slovenska vojska oziroma Generalštab Slovenske vojske, ki je izdajatelj Sodobnih vojaških izzivov, želi prispevati k razvoju varnostnih vsebin v Republiki Sloveniji, še posebej na področju obrambnega sistema. Zakon o obrambi pravi, da minister določa vojaškostrokovno literaturo, številni drugi akti pa jo urejajo podrobneje. Med vojaškostrokovno literaturo spadajo doktrine, navodila, metode in merila za merjenje stopnje usvojenih znanja in veščin, učbeniki, priročniki in periodične publikacije. Organizacijske enote Slovenske vojske, v katerih nastaja vojaškostrokovna literatura, so sektor J5 za razvoj in mednarodno sodelovanje, J7 za vojaško usposabljanje ter Center vojaških šol za razvoj vojaških učbenikov, priročnikov in skript.

Slovenska vojska, Ministrstvo za obrambo in Republika Slovenija smo sestavni del mednarodnega varnostnega okolja. Prav je, da skrbimo za kakovosten razvoj svojega obrambnega sistema, zato da bomo lahko, če bo treba, pomagali tudi drugim v mednarodnem okolju. Kakovosten obrambni sistem potrebujemo zato, da bomo varni doma. Sodobni vojaški izzivi so tako ena izmed odličnih možnosti za predstavitev znanja, zamisli in razmišljanja o razvoju slovenskega obrambnega sistema. Zakaj omenjamo obrambni sistem in ne vojaškega? Ker eno brez drugega 
ne gre. Tokratna številka je nekaj posebnega. Na naše vabilo k pisanju so se odzvali le »vojaki«. Je to naključje?

Alojz Šteiner je pripravil članek z naslovom Za boljše razumevanje transformacijske paradigme in transformacije oboroženih sil, v katerem predstavlja različne izraze za pojave, ki se zadnjih nekaj desetletij uporabljajo v povezavi s spremembami na obrambno-vojaškem področju. Kot pravi, izhaja iz dejstva, da se ti pojavi spreminjajo po koncu hladne vojne $\mathrm{v}$ različnih strokovnih in znanstvenih virih. V obrambnovojaški praksi se opisujejo z več izrazi, ki so lahko sinonimi za opis enakih pojavov, večkrat pa so uporabljeni za opis povsem različnih, čeprav so si na prvi pogled precej podobni. Kako je torej z izrazi za tovrstne pojave, pojasnjuje avtor v članku.

Ali civilni nadzor podpira ali ovira vojsko pri doseganju učinkovitosti, nujne za uresničevanje njenega poslanstva, se sprašuje Branimir Furlan v članku z naslovom Neučinkovitost vojske kot pokazatelj neustreznega civilnega nadzora (1). Obljublja nadaljevanje članka, a že zdaj ponudi analitični model, ki omogoča ugotavljanje vzročno-posledične povezave med nadzorom in učinkovitostjo. Kako pa merimo učinkovitost vojske? Avtor je oblikoval svojo definicijo.

Vloga združenega bojevanja rodov v okolju hibridnega vojskovanja v kontekstu trenutnega stanja in razvojnih možnosti SV je naslovna tema Viktorja Potočnika. Pravi, da pod pojmom hibridnega vojskovanja ne najdemo velikih revolucionarnih sprememb v oblikah in metodah vojskovanja in da je za zmago v sodobnem spopadu še vedno zelo ustrezen koncept združenega bojevanja rodov, ki pa ga je treba razumeti v okviru sodobnega vojskovališča, katerega glavni značilnosti sta boj v informacijskem prostoru in »hibridnost«. Je hibridnost nov pojav in kaj to sploh je?

Eno pomembnih področij za razvoj obrambnega sistema je področje upravljanja človeškega kapitala. Posvetil se mu je Milan Žurman v članku z naslovom Logistična podpora Slovenske vojske v povezavi z učinkovitim sistemom upravljanja človeškega kapitala. Ugotavlja, da se ambicije in potrebe uporabnikov v Slovenski vojski po zagotavljanju sodobne logistične podpore ne zmanjšujejo, temveč ostajajo na enaki ravni ali se celo povečujejo. To vpliva na upravljanje človeškega kapitala. Svoje ugotovitve in predloge avtor deli z bralci v članku.

Marjan Zupančič, Karmen Poklukar in Rafael Kolbl so avtorji članka z naslovom Natov center odličnosti za gorsko bojevanje - izzivi, priložnosti in interesi. Predstavljajo novo mednarodno akreditirano organizacijo v Sloveniji za gorsko bojevanje. Uporabijo Blaznikov opis, da so centri odličnosti namenjeni preoblikovanju zavezniških sil, povečanju in izboljšanju posebnih zmogljivosti ter predvsem učinkovitejši uporabi že oblikovanih zmogljivosti članic zveze ter partnerskih držav. Podrobno opišejo izzive, priložnosti in interese, ki jih obljubljajo v naslovu.

Vabljeni k sodelovanju! 